\title{
Smarsh, S. (2020) She Come By it Natural: Dolly Parton and the Women Who Lived Her Songs. Simon and Schuster.
}

\section{Review by Pamela Fox}

Country music star Dolly Parton has garnered mass attention since she lit out on a bus from her Appalachian home in 1964. But as Sarah Smarsh surmises in her new book, that spotlight frequently singled out this singer/songwriter/actress/business mogul for the 'wrong'-i.e. misogynist-reasons. She Come By it Natural: Dolly Parton and the Women Who Lived Her Songs finds a sweet spot between celebrity biographies and academic studies about this legendary performer by offering a distinct working-class feminist perspective gleaned from Smarsh's own experience within her rural female working-class family. Those familiar with Smarsh's bestselling book Heartland: A Memoir of Working Hard and Being Broke in the Richest Country on Earth will be pleased to get reacquainted with her mother and Grandma Betty, who lived the kind of lives that Parton knew intimately and ultimately shared with the world. This autobiographical component doesn't simply serve as a testament to Parton's devoted fan base; it accentuates a particular kind of gendered and classed knowledge that Smarsh finds all too lacking in elite spaces. Privileging working-class rural speech, she invites similar readers to enjoy being the central audience for her recuperation of all things Dolly. But make no mistake: she equally calls out the professional classes, as well as activists, on their class biases; their ignorance of workingclass feminism; their dismissal of country music as politically retrograde; and their view of Parton as a contradictory, improbable feminist. Smarsh acknowledges that Dolly doesn't identify as such in name but argues that 'her work is a nod to women who can't afford to travel to the march, women working with their bodies while others are tweeting with their fingers' (p. xiii).

Originally published in 2017 as a four-part series of essays for the alternative country music journal No Depression, the book version expands the original temporal framework of Smarsh's study from the devastating 2016 Presidential election to the momentous 2020 contest. It may seem curious to cast an aging female country music icon, previously 'best known ... as the punch line of a boob joke' (p. ix), as the healing unifier of our highly polarized political climate. But Smarsh has gotten our attention. In both election years, she claims, '[p]olitical headlines were fixating on a hateful, sexist version of rural, working-class America that I did not recognize. Dolly's music and life contained what I wanted to say about class, gender, and my female forebears: That country music by women was the formative feminist text of my life' (p. xii). Arguing that 'Parton was brilliant not just in songwriting and singing but in gender performance and business,' she lauds $21^{\text {st }}$-century fans for seeing what 'was there all along ... but for the blinders of patriarchy: Parton's artistry, intellectual depth and self-fashioned paradoxes that slyly comment on our country's long-denied caste system' (pp. x-xi).

She Comes By It Natural sets out to investigate this shift in Parton's reputation over the decades, grafting the history of the U.S. women's movement onto the coordinates of her life span. Smarsh begins with the state of women's oppression in 1946, the year of Dolly's birth, noting, '[w]omen 
in poverty and women of color fared the worst, on the losing end of societal structures favoring wealth and whiteness. Meanwhile, their contributions to women's progress went unnoticed, undocumented, and ill-understood' (p. x). Those offerings may have been invisible to feminist historians of the movement because they appear so counterintuitive within mainstream spheres. In Dolly's case, she contested small town sexism with her own 'town tramp' image. Smarsh hails Parton's lifetime of work to revamp 'this frequently vilified class of American woman,' deeming it 'at once the greatest self-aware gender performance in modern history and a sincere expression of who Parton is. ... the working-class woman whose feminine sexuality is often an essential device for survival and yet whose tough presence might be considered 'masculine'" (p. 6). The book rightly lingers on Dolly's early protean songwriting that documents the dangers for rural working-class women: violent men, neglected and shamed mothers and daughters, dying children. From the beginning, this talented young woman knew that she needed to leave her home in order to save herself and tell the world why. Smarsh counters 'intellectual knowledge' with Parton's 'experiential knowing' (p. 49), arguing, 'working-class women might not be fighting for a cause with words, time, and money they don't have, but they possess an unsurpassed wisdom about the way gender works in the world' (p. 49). She parallels Dolly's numerous escape acts throughout her career with those by women in her family and community: 'airplane factory workers, cafeteria cooks, discount-store cashiers, diner waitresses, fast-food workers - all contain a common thread of dramatic, self-preserving departures' (p. 55).

Yet Smarsh doesn't (entirely) gloss over the price Parton paid for her insistent autonomy. We learn that while in her thirties, she had a breakdown and became suicidal during another pivotal feminist moment, defeat of the Equal Rights Amendment in 1982. After seeking help, Parton fired employees who failed to heed her authority, concentrated on her physical and mental health, and transformed her business plan. Having 'conquered a man's world the best a woman could and found it a place that would treat her like dirt even when she was on top,' she did the next best thing: she built 'her own damn world,' Dollywood, in the Smoky Mountains of Tennessee (pp. 115-116). While clearly crafted to enhance her assets portfolio, Parton also designed her theme park to employ those without jobs in her home state (approximately 3,500) and to showcase its mountain culture. Smarsh acknowledges that skeptics could surmise some exploitation here but counters with Dolly's signature tactic of beating others to the punch: 'To fight the dehumanization of the rural poor, she got rich, went home, and turned Appalachia into a performance before rich, urban developers could' (p. 155). (However, a later dinner-theatre enterprise named Dixie Stampede disappoints the author for its 'white-washed nostalgia for the Antebellum South' (p. 159).)

In the final pages, Smarsh revels in Dolly's world-wide success but laments the stagnant gender politics that still govern country music radio, which typically airs on average seven out of sixty songs by women artists. She nods to '[t]oday's young female singer-songwriters who follow in Parton's footsteps - old twang, modern ideas, gothic country themes, spiritual vulnerability' who may be poised to take up her mantle (pp. 144-45). Citing a Slate media critic's comparison of Dolly to Nicki Minaj, Smarsh adds, 'Parton helped pioneer the sort of feminism on display in contemporary pop music--serving up T\&A on your own terms, subverting objectification by having a damn good time with it - but perhaps not while speaking the same language as progressive America' (pp. 170-71). Earlier in the book, she insists that for poor and workingclass women, 'the fight to merely survive is a declaration of equality that could be called 'feminist.' 
But here's the thing: ... they don't give a shit what you call it' (p. 48, my emphasis). I concur. Yet I'm a bit uncomfortable with Smarsh's culminating veneration of this artist, whose 'place in culture finally shifts from objectified female body to the divine feminine - a sassy priestess in high heels' (p. 149). Maybe my academic knowledge is clashing with my 'experiential knowing' of workingclass feminism, but I prefer to think of Dolly less as a deity and more as a grounded musical and narrative force who brings together a plethora of races, genders, sexualities, leftists, conservatives. Nevertheless, I admire this book's all too rare space for poor and working-class women to idolize one of their own.

\section{Reviewer Bio}

Pamela Fox is Professor of English at Georgetown University, where she teaches classes on British and American working-class literature, environmental racial justice (Hurricane Katrina), and the cultural politics of motherhood. She is the author of two books, Class Fictions: Shame and Resistance in the British Working-Class Novel, and Natural Acts: Gender, Race, and Rusticity in Country Music, and co-editor of Old Roots, New Routes: the Cultural Politics of Alt.Country Music. She has written about transnational adoption, contemporary music memoir, and is beginning work on a digital humanities project, 'Reading Motherhood,' with her co-teacher and colleague Elizabeth Velez. 